\title{
Conviviality Vis-à-Vis Cosmopolitanism and Creolisation: Probing the Concepts
}

\author{
Oscar Hemer, Maja Povrzanović Frykman \\ and Per-Markku Ristilammi
}

An online search yields the following synonyms for the adjective convivial: (1) friendly, agreeable (a convivial atmosphere); (2) fond of feasting, drinking and merry company, jovial; and (3) of or befitting a feast, festive.

Clearly, these are not the primary connotations to the concept that is currently becoming a buzz-word in academia, to the extent that one may even speak of a "convivial turn" within certain fields of the social sciences

\section{O. Hemer $(\bowtie)$}

Faculty of Culture and Society, School of Arts and Communication, Malmö University, Malmö, Sweden

e-mail: oscar.hemer@mau.se

M. Povrzanović Frykman

Faculty of Culture and Society, Department of Global Political Studies, Malmö University, Malmö, Sweden

e-mail: maja.frykman@mau.se

P.-M. Ristilammi

Faculty of Culture and Society, Department of Urban Studies, Malmö University, Malmö, Sweden

e-mail: per-markku.ristilammi@mau.se

(C) The Author(s) 2020

O. Hemer et al. (eds.), Conviviality at the Crossroads, https://doi.org/10.1007/978-3-030-28979-9_1 
(Lapina 2016; Neal et al. 2013; Valluvan 2016; Wise and Noble 2016). As Encarnación Gutiérrez Rodríguez shows in her contribution to this book (Chapter 6), the etymology of conviviality as it is used today stems from the Spanish term convivencia, which was originally coined to describe the pluri-cultural and pluri-confessional "living together" in medieval Spain (al-Andalus). It was this moral meaning that Ivan Illich transferred to his suggested "tools for conviviality" (Illich 1973). The convivial society that Illich envisioned was a post-industrial, localised society of "autonomous individuals and primary groups" (Ibid., 10). The recent debate on conviviality has however almost entirely emanated from Paul Gilroy's refashioning of the concept, 30 years later, against the backdrop of social, racial and religious tensions in post-imperial Britain, "at the point where 'multiculturalism' broke down" (Gilroy 2004: xi). In Gilroy's interpretation, conviviality denoted the acceptance and affirmation of diversity without restaging communitarian conceptions of ethnic and racial difference. This understanding has subsequently been refined to provide "an analytical tool to ask and explore in what ways, and under what conditions, people constructively create modes of togetherness" (Nowicka and Vertovec 2014: 2).

When we formed the Conviviality at the Crossroads research network at Malmö University, largely inspired by the 2015 refugee migration and its aftermath, we agreed on using "conviviality" as a lens for examining the current challenges to (liberal) democracy, in Europe and beyond. However, we also decided at the outset that conviviality should be applied in conjunction with the inter-related concepts of "cosmopolitanism" and "creolisation", in order to provide both tools for analysis and forms for cross-cutting communication. This book puts forward conceptual discussions of these three concepts, using examples concerning the situation after the 2015 refugee migration in Sweden and Denmark as well as examples with different scopes in both time and space (e.g., the chapters on the German Enlightenment and contemporary South Africa). The book aims to track notions of conviviality, cosmopolitanism and creolisation in terms of the histories of their theoretical treatment as well as the conditions of their emic uses. Such tracking, as suggested by Magdalena Nowicka in Chapter 2, also reveals that different notions have been used to address the very same issue of "living-with-difference", and helps us understand the scholarly struggles with the ambivalences they contain. Moreover, the book is a reminder of how ideas relevant to the field of our concern move and interact across time and scholarly contexts. For example, Ivan Illich's understanding of conviviality as a stance with "the potential of addressing an intrinsic ethical 
value underlining the interconnectedness and mutual dependency between the human, the planet and the cosmos", discussed by Gutiérrez Rodríguez in Chapter 6, resonates with Rosi Braidotti's radical reconceptualisation of the notion of cosmopolitanism referred to by Nowicka in Chapter 2.

In the case of the first two concepts, the close connection is obvious. For Gilroy conviviality was precisely a substitute for cosmopolitanism, which in his view had been hijacked as a pretext for Western "supposedly benign imperialism" in the aftermath of $9 / 11$ and the war on terror (Gilroy 2004: 66). What he rejected was hence not the cosmopolitan ideal as such, but its interpretations which allegedly did not see a contradiction between this ideal and the categories that confine people to particular, hierarchically located groups. In contrast, the less ideologically burdened concept of conviviality denoted an ability to be at ease in contexts of diversity.

Leading scholars in this debate, most notably Magdalena Nowicka, with Steve Vertovec (Nowicka and Vertovec 2014) and Tillman Heil (Nowicka and Heil 2015), follow and elaborate on Gilroy's suggestion that conviviality is a more productive analytical tool than cosmopolitanism. Yet, the latter, with its roots in ancient Greece and its prominent presence in the European history of ideas, has of course not succumbed to this newcomer. The literature on cosmopolitanism veritably exploded in the 1990s, as a key element in the globalisation debate worldwide, and has had new momentum in the last decade, parallel to that of conviviality (Appiah 2006; Beck 2006; Beck and Grande 2007; Beck and Sznaider 2016; Braidotti 2013; Brown and Held 2010; Held 2010; Glick Schiller and Irving 2015; to name just a few).

But, as noted above, rather than replacing one concept with the other, this book seeks to explore the interconnections-commonalities and differences-between them. For example, in recent research within urban studies, conviviality has been used as an antidote for neoliberal commercialisations of urban space resulting in the displacement of unwanted groups (cf. Bates 2018). As is pointed out by Magdalena Nowicka (Chapter 2), the notion of conviviality runs the risk of being reduced to a prescriptive, or even normative, concept whereby physical surroundings could be "tweaked" in order to create social cohesion. We would rather regard it as a perspectivising notion by which we can achieve a critical understanding needed for coping with the social tensions that inform life in contemporary cities. Such an approach can also relate to the notions of "vernacular cosmopolitanism" (Bhabha 1996; Appiah 1998) or "cosmopolitanism from below" (Appadurai 2002, 2013). 
"Creolisation" may at a first glance appear to be of a different order than the other two concepts. Its articulation was regionally grounded in the New World, especially in the Caribbean, as a means of analysing and expressing processes of cultural intermingling and cross-fertilisation. As a generalised concept, creolisation had its heyday in the late 1980s and early 1990s, when anthropologist Ulf Hannerz and poet-philosopher Édouard Glissant independently of each other proposed it as a denominator for the globalisation of culture- “a world in creolisation" (Hannerz 1987; Glissant 1990). ${ }^{1}$ It is worth remembering that the creolisation debate preceded and informed the discussion on "globalisation", which did not emerge among economists or political scientists, but in cultural studies. ${ }^{2}$

As cultural aspects of globalisation were overshadowed by economic and political ones, creolisation seemed to lose attraction or be returned to its origin in linguistics and local history. But the generalised use of the concept has experienced a revival in recent years, parallel to the resurgence of cosmopolitanism and conviviality (Cohen 2007; Cohen and Toninato 2010; Monahan 2011; Lionnet and Shih 2011; Gutiérrez Rodríguez 2011; Gutiérrez Rodríguez and Tate 2015). Robin Cohen makes the following comprehensive definition of what he claims to be the key component in cultural globalisation:

When creolisation occurs, participants select particular elements from incoming or inherited cultures, endow these with meanings different from those they possessed in the original cultures and then creatively merge these to create new varieties that supersede the prior forms. (Cohen 2007)

Although the term "creolisation" has so far seldom been referred to in the conviviality/cosmopolitanism debate, it does appear under the guise of other related terms (e.g., hybridisation and cultural mélange) as an implicit supplement to the other two. For example, Nowicka and Heil (2015) talk of two parallel processes that frame contemporary cosmopolitanism: "border-crossing and hybridization on a world scale, and bordering and consolidation of national, or ethnic, groups". "Hybridization" is here presumably synonymous with "creolisation", and the suggested parallel corresponds well to Glissant's key notions of Relation vs Essence. ${ }^{3}$ Creolisation presupposes a process of inter-mingling without beginning or end, whose outcome is as per definition unpredictable. Moreover, as Thomas 
Hylland Eriksen demonstrates in this volume (Chapter 3), there is a common denominator in the discussion on "superdiversity", which could be regarded as a European relative to the Caribbean notion of the "creole".

A popular and persistent perception of cosmopolitanism is that it represents an ideal for an elite of globetrotting academics and executives, far removed from the reality of ordinary people. The tinge of elitism that undoubtedly adheres to the concept is however countered by several articulations of "vernacular cosmopolitanism". Globalisation and the digital revolution have undoubtedly added a new dimension to the contemporary debate, by involving actors who were previously not in a position to become "world citizens". Arjun Appadurai, who coined the notion of "globalisation from below", uses the sister term "cosmopolitanism from below" to describe the situation among the urban poor in Mumbai, India, where he has been carrying out participatory research with Shack/Slumdwellers International $^{4}(2002,2013)$.

The main critique against cosmopolitanism as a concept remains however the one articulated by Gilroy and many postcolonial theorists before and after him; that it is rooted in a Eurocentric worldview. To be truly cosmopolitan it would need to be self-reflective and critically analyse its own roots-thereby also questioning its own analytical sense and value. Rosa Braidotti (2013) sees two possible solutions to this inherent dilemma: either rejection or radical change.

So far, the impulses of global self-reflexion and a radical rethinking of the world have mainly, although not exclusively, been provided by scholars and writers in or from the Global South. Dipesh Chakrabarty attempted "the task of exploring how [European] thought - which is now everybody's heritage and which affects us all - may be renewed from and for the margins" (Chakrabarty 2000: 16). In his case, it was a matter of translating the categories of modern European science to a South Asian context, but the reverse could supposedly be applied to an analysis of the crises in presentday Europe - of the refugee migration, which is not a crisis in Europe but on its borders, and the crises of the European Union (EU) and of liberal democracy, which are indisputably real.

Ulrich Beck's theory of the global risk society $(1998,2009)$ is an important contribution to the contemporary debate. To Beck, cosmopolitanism is an inescapable feature of globalisation, ${ }^{5}$ not a (utopian) vision for the future, but the global reality here and now. The challenge is to acknowledge this cosmopolitan reality - to step out of the still prevailing nationstate perspective and take a cosmopolitan viewpoint. The global risk is an 
anticipation of catastrophe, but may therefore also be the antidote to disaster, by presenting an opportunity for metamorphosis (Verwandlung); that is, new ways of generating and implementing norms. Hiroshima and the Holocaust are examples of watershed events with a "before" and an "after", and, as he suggested in one of his last articles (Beck 2014), climate change may provide a similar moment of metamorphosis.

Urgent global challenges not only require a global (cosmopolitan) perspective; to research contemporary society we moreover need a cosmopolitan method, what Beck defines as analytical cosmopolitanism. In response to Beck, Nowicka and Heil (2015: 1) propose the humbler analytical conviviality, which focuses on "the everyday processes of how people live together in mundane encounters, of how they (re)translate between their sustained differences and how they (re)negotiate minimal consensuses". Their key question could be formulated as: How is the minimal sociality possible? Again, this "non-normative" notion of conviviality clearly speaks to Glissant's concept of Relation, as a non-hierarchical and non-reductive system of interconnectedness (see Chapters 12 and 14).

Glissant never used the term conviviality, but he comes very close to what we regard as an exemplary definition. Against the "false transparency" of a world dominated by the West, he posits "the penetrable opacity of a world in which one exists, or agrees to exist, with and among others" (Glissant 1997 [1990]: 114). South African scholar Zimitri Erasmus gives another viable definition without pronouncing the word in her proposal to cultivate an ethos of contesting inequality and living-together-in-difference (Erasmus 2017:23-24). One of the first to put conviviality and creolisation in explicit scholarly dialogue was Encarnación Gutiérrez Rodríguez (2011, 2015; see also Chapter 6), who even proposes the definition of creolisation as transversal conviviality.

In 2014 a group of francophone intellectuals, led by sociologist Alain Caillé and including Chantal Mouffe, signed The Convivialist Manifesto: A Declaration of Interdependence. ${ }^{6}$ It was a plea for a new "art of cohabitation" in the face of the urgent threats to humankind in the early twenty-first century. The manifesto coins the term convivialism as a normative "-ism"; a conception of society based on "human cooperation and mutual respect for maximum diversity". Convivialism does not rule out conflict. On the contrary-and this is where Chantal Mouffe's influence may be detectedit accepts and affirms conflict as a necessary and productive feature of life, provided that it is based on the agreement of a shared world. The basic convivialist principle is mutual aid, characteristic of voluntary organisations, 
families and friendship networks - which interestingly, as Nowicka and Heil (2015) point out, resembles Illich's convivial order of "autonomous individuals and primary groups".

This radical activist agenda was in the German debate criticised for neglecting the solidarity and voluntarism "within the neo-liberal regimes" that became manifest in the responses to the refugee migration in 2015, not least in Germany and Sweden (see Chapter 9 by Povrzanović Frykman and Mäkelä). The "Refugees Welcome" and other spontaneous initiatives appear as examples of a more pragmatic form of conviviality (without the -ism) that would be in accordance with Nowicka and Heil's conception.

The urgency of today's global predicament is the recurring argument in the discussion of all three concepts. In the anthology The Creolization of Theory (2011), Françoise Lionnet and Shu-mei Shih make an interesting parallel between the dynamics of what they call the dark side of globalisation and of the early process of creolisation, which emerged from violent encounters that were colonial and imperial (Lionnet and Shih 2011: 24):

In today's world of financial meltdowns and immense power differentials exacerbated by globalisation, people from all areas of the planet are experiencing something akin to the "shock of space and time" of early plantation cultures. (Lionnet and Shih 2011: 30)

While, as Lionnet and Shih underscore, the strength of the concept arises from its historical specificity, the historical connotation to the global slave trade is most probably the reason why creolisation evokes an indefinite uneasiness among (white) Westerners "Caucasians" in the curious North American racial typology ${ }^{7}$ ), as opposed to both amiable conviviality and "elitist" cosmopolitanism. Slavery, the fundament of the colonial world system, remains a blind spot to the modern European mind. Even enlightened liberals are reluctant to admit that colonialism is "the underside of Modernity" (Mignolo 2012); that the modern world arguably was born in the plantation economies of the New World. Some of the liberals' militant opponents on the left, in turn, fail to acknowledge that the decolonisation they propose de facto also implies de-modernisation. But the colonial encounter cannot be undone. This is the crucial point. And it is also a principal reason why creolisation is a necessary complement to the other two concepts, or a "recipe for conviviality", as Eriksen puts it (see Chapter 3). 
Whereas conviviality may be interpreted as a formula for "living with difference" yet side-by-side and not intermingling - as in common notions of multiculturalism-creolisation is inevitably "messy" and impure. It is in this "messy" crossroads of concepts with political implications that we situate this book. A common denominator is the shared interest of contributing authors in moving beyond the binary thinking that currently prevails (Glick Schiller 2012), in terms of methodologies as well as analytical concepts, and political implementations.

Magdalena Nowicka's contribution (see Chapter 2) has a twofold aim: first, looking back at the last years of the debate with a short overview of the main themes and fields of application of the notion of conviviality, notably concerning migration and diversity. Second, reflecting on conviviality as a mode of thinking of human togetherness. The main question is how the myth of individuality shapes research in this field, and how this research could be different if it introduces the notion of conviviality.

Chapter 3, by Thomas Hylland Eriksen, draws on the literature on creolisation as well as on conviviality, but its main thrust is in a description of the Creole identity in the Indian Ocean island states of Mauritius and the Seychelles. Eriksen is comparing the Creole identity to that of bounded, endogamous groups and thereby showing that conviviality in the public sphere is compatible with group boundaries, which Creoledom is not. In this sense, the Creole identity represents an inoculation against divisive identity politics.

Ulrike Wagner's contribution (Chapter 4) looks back and investigates a prominent late 18th-century conception and use of the term conviviality. Inspired by his regular visits to social gatherings organised by Henriette Herz (1764-1847), one of Berlin's most prominent salonières of the time, the German philosopher and theologian Friedrich Daniel Schleiermacher (1768-1834), contributed with Toward a Theory of Sociable Conduct (1799) a theory of conviviality that bears interesting and unexplored resemblances to today's conceptions.

Rebecka Lettevall (Chapter 5 ) explores the utopian aspects of the notion of cosmopolitanism from a starting point of Kant's definition of cosmopolitan right. Since cosmopolitanism is a contested concept without one solid definition, parts of its meaning have, in the present-day, been substituted by the concept of conviviality. Inspired by Ruth Levitas (1990, 2013), Lettevall claims that a better solution would be to see cosmopolitanism as a utopian method in the search for directions for the future. 
Informed by the work of Ivan Illich on conviviality and Édouard Glissant on creolisation, Encarnación Gutiérrez Rodríguez (Chapter 6) critically probes the conceptual and visionary implications of creolising conviviality. Creolisation as a rhizomatic relational conceptualisation of society departs from the critical understanding of contemporary societies as entrenched in historically produced racialised hierarchies, resulting in economic and social inequalities which impede living together based on equal economic distribution and social justice. Addressing these inequalities requires a decolonial ethics of creolising conviviality.

Deniz Neriman Duru (Chapter 7) considers the meanings of conviviality in the context of different research projects. She uses data from a comparative research project at the EU level to categorise different types of what she sees as convivial solidarity actions in connection to the refugee migration of 2015. She argues that crises can be both an opportunity and a threat for the mobilisation of transnational solidarity support actions.

Erin Cory (Chapter 8) draws on a research project in which conviviality becomes a prism to understand media practices related to migration and refugees and discusses how the concept is best appropriated as a methodological tool in research designs informing current and future activist-based studies. Questions posed are: What can conviviality do, or rather, what can researchers do with it in their efforts to understand the connections between media, mediation and migration? How can researchers across disciplines do conviviality as part of an interventionist research praxis?

Maja Povrzanović Frykman and Fanny Mäkelä (Chapter 9) connect the notion of cosmopolitanism to the field of volunteering. Using the aftermath of the Refugees Welcome civil initiatives that emerged in Sweden when more than two thirds of some 160,000 asylum seekers entered the country in the last few months of 2015, their chapter explores volunteers' reflections on their work in the years that followed. Without using the notion of cosmopolitanism, these volunteers outline cosmopolitan concerns in the moral and political realm.

In Chapter 10, Per-Markku Ristilammi highlights a specific kind of normative state-driven conviviality through the example of the Öresund Bridge that connects Sweden and Denmark. Ristilammi shows how the concept of conviviality can be used in an analysis of the changing roles of the state. Ethnographic examples from border-crossing experiences at the bridge in 2000, in 2015, when border controls were introduced due to refugee arrivals, and in the present-day, show how a breakdown of conviviality opens up for a new form of biopolitical regime at the border. 
Hugo Boothby (Chapter 11) explores the tension evident between conviviality and hostility in the experiences of post-war Caribbean migration to Great Britain and how this finds expression in popular music. The music that forms the primary site of analysis for this chapter is that which demonstrates radical intermixture, combining influences from Africa, the Caribbean, the United States and the United Kingdom.

Anders Høg Hansen (Chapter 12) analyses break-away, racialised, migratory and postcolonial experiences through two cases that portray reclusive individuals caught in, and making their way through, a politics of a convivial nature. The discussion evolves around Glissant's notion of opacity and the concept of reclusive openness that the author proposes in order to capture some of the ambiguities of diasporic experiences.

Oscar Hemer (Chapter 13) assumes as a hypothesis that the underlying structure of nationalism, identity politics and xenophobia, can be explicated by the British anthropologist Mary Douglas' conceptual dichotomy Purity-Impurity (Douglas 1966). Applied to a South African context, the purity-impurity matrix becomes a tool for interrogation of apartheid and its vision of "separate development" as suppressed creolisation. This is done by means of an experimental cross-genre (literary and academic) approach that aspires to be congenial with the subject.

In the chapter concluding the volume (Chapter 14), Kerry Bystrom uses the notions of convivial urban encounters and opacity to discuss xenophobic violence against black African immigrants in South Africa. To envision alternatives to this violence the chapter revisits Khalo Matabane's Conversations on a Sunday Afternoon (2005), a hybrid fiction-documentary film that traces a South African poet's chance meeting with a Somali refugee in Johannesburg and the encounters with other immigrants it enables. Matabane shows how both conviviality and opacity are necessary to seeing Johannesburg anew and making it a truly hospitable environment.

Finally, let us mention that the subtitle of this book, "The poetics and politics of everyday encounters", is a tribute to one of the most influential books in anthropology of the late twentieth century, Writing Culture: The Poetics and Politics of Ethnography (1986), edited by James Clifford and George E. Marcus. We are of course not assuming even a faint resemblance to its importance, but we do wish to state our openness to cross-disciplinary and cross-genre experimentation that aims at being congenial with the subject. 


\section{Notes}

1. Glissant first used the term creolisation in 1981, interestingly in opposition to Creolité [creoleness], which originated as an identity-based defence of a homogenised creole language. Against this linguistic militancy, he proposed a definition of Antillanité [caribbeanness] for which linguistic formations are but one of many results of the colonial encounter, and in the catalogue of such cultural realities he mentions, almost in passing, "the general cultural phenomenon of creolisation" (Glissant 1989 [1981]: 222, quoted by Chancé $2011[2005])$.

2. The coining of the term "globalisation" is commonly attributed to US American cultural sociologist Roland Robertson, who defined it as "the compression of the world and the intensification of the consciousness of the world as a whole" (Robertson 1992).

3. The choice of one or the other term appears to be a matter of language and scholarly tradition (English vs French, Spanish, Portuguese) or personal preference. Unlike his mentor Stuart Hall, Gilroy rarely refers to creolisation, scholars from the South Asian subaltern studies tradition (Bhabha, Chatterjee, Spivak), generally use the terms hybridity/hybridisation, whereas otherwise Anglo-oriented South African scholars have adopted creolisation (Nuttall, Hofmeyr, Erasmus). To Glissant the terms are however not interchangeable; he clearly distinguishes creolisation from métissage (which would be the French equivalent to hybridity/hybridisation):

If we posit métissage as, generally speaking, the meeting and synthesis of two differences, creolisation seems to be a limitless métissage, its elements diffracted and its consequences unforeseeable. (Glissant 1997 [1990]: 34)

4. Shack/Slumdwellers International is a transnational agency network that started through the joint mobilisation of diverse grass-roots organisations in Mumbai in the late 1990s. It has now spread over three continents, with branches in Africa and Latin America, and its head office in Cape Town.

5. Although it may never have occurred to Beck, his depiction of cosmopolitanism as an unpredictable and unmanageable feature of an increasingly complex and interconnected world bears striking resemblance to Glissant's conception of creolisation and what he in more poetical words describes as the emergence of the Tout-Monde (1997).

6. Available in full and abridged versions in French and English at the website of "the convivialists", http://www.lesconvivialistes.org.

7. The genealogy of "Caucasian" goes back to the ancient slave trade of predominantly white women in the Caucasus. It was the racialised conception of these (slave) women as the embodiment of beauty that sparked the invention of the "Caucasian race" as white, beautiful and superior (Erasmus 2017: 52). 


\section{REFERENCES}

Appadurai, A. 2002. "Deep Democracy, Urban Governmentality and the Horizon of Politics." Public Culture 14 (1): 21-47. https://doi.org/10.1215/ 08992363-14-1-21.

Appadurai, A. 2013. The Future as Cultural Fact: Essays on the Global Condition. London: Verso Books.

Appiah, K. A. 1998. "Cosmopolitan Patriots." In Cosmopolitics: Thinking and Feeling Beyond the Nation, edited by P. Cheah and B. Robbins, 91-116. Minneapolis, $\mathrm{MN}$ : University of Minnesota Press.

Appiah, K. A. 2006. Cosmopolitanism: Ethics in a World of Strangers. New York and London: W. W. Norton \& Co.

Bates, C. 2018. "Conviviality, Disability and Design in the City." The Sociological Review 66 (5): 984-999.

Beck, U. 1998. World Risk Society. Cambridge: Polity Press.

Beck, U. 2006. The Cosmopolitan Vision. Cambridge: Polity Press.

Beck, U. 2009. World at Risk. Cambridge: Polity Press.

Beck, U. 2014. "How Climate Change Might Save the World." Harvard Design Magazine 39. Available from: www.harvarddesignmagasine.org/issues/ 39. Accessed June 15, 2019.

Beck, U., and E. Grande. 2007. Cosmopolitan Europe. Cambridge: Polity Press.

Beck, U., and N. Sznaider. 2016. "New Cosmopolitanism in the Social Sciences." The Routledge International Handbook of Globalisation Studies, edited by B. S. Turner and R. J. Holton, 572-588. London: Routledge.

Bhabha, H. 1996. "Unsatisfied: Notes on Vernacular Cosmopolitanism." In Text and Nation, edited by L. Garcia-Morena and P. C. Pfeifer, 191-207. London: Camden House.

Braidotti, R. 2013. "Becoming-World." In After Cosmopolitanism, edited by R. Braidotti, P. Hanafin, and B. Blaagaard, 8-28. Abingdon: Routledge.

Brown, G. W., and D. Held. 2010. The Cosmopolitanism Reader. Cambridge and Malden, MA: Polity Press.

Chakrabarty, D. 2000. Provincializing Europe: Postcolonial Thought and Historical Difference. Princeton, NJ: Princeton University Press.

Chancé, D. 2011 [2005]. "Creolization. Definition and Critique." In The Creolization of Theory, edited by F. Lionnet and S.-m. Shih. Durham, NC: Duke University Press [orig. "Créolisation." In Vocabulaire des études francophones: Les concepts de base, edited by M. Beniamino and L. Gauvin. Paris: Pulim].

Clifford, J., and G. E. Marcus, eds. 1986. Writing Culture: The Poetics and Politics of Ethnography. Berkeley, Los Angeles, and London: University of California Press.

Cohen, R. 2007. "Creolisation and Cultural Globalisation: The Soft Sounds of Fugitive Power." Globalizations 4 (3): 369-384. https://doi.org/10.1080/ 14747730701532492 . 
Cohen, R., and P. Toninato. 2010. "The Creolization Debate: Analysing Mixed Identities and Cultures." In The Creolization Reader, edited by R. Cohen and P. Toninato, 1-21. London: Routledge.

Douglas, M. 2002 [1966]. Purity and Danger: An Analysis of Concept of Pollution and Taboo. London: Routledge.

Erasmus, Z. 2017. Race Otherwise: Forging a New Humanism for South Africa. Johannesburg: Wits University Press.

Gilroy, P. 2004. After Empire: Melancholia or Convivial Culture? London: Routledge.

Glick Schiller, N. 2012. "Situating Identities: Towards an Identities Studies Without Binaries of Difference." Identities: Global Studies in Culture and Power 19 (4): 520-532. https://doi.org/10.1080/1070289x.2012.741525.

Glick Schiller, N., and A. Irving, eds. 2015. Whose Cosmopolitanism?: Critical Perspectives, Relationalities and Discontents. New York, NY: Berghahn Books.

Glissant, É. 1990. Poétique de la Relation. Poétique III. Paris: Éditions du Seuil.

Glissant, É. 1997. Poetics of Relation. Translated by Betsy Wing. Ann Arbor: University of Michigan Press.

Gutiérrez Rodríguez, E. 2011. "Politics of Affects: Transversal Conviviality." Transversal 1. http://eipcp.net/transversal/0811/gutierrezrodriguez/en.

Gutiérrez Rodríguez, E. 2015. "Archipelago Europe: On Creolizing Conviviality." In Creolizing Europe. Legacies and Transformations, edited by E. Gutiérrez Rodríguez and S. A. Tate, 80-99. Liverpool: Liverpool University Press.

Hannerz, U. 1987. "The World in Creolization.” Africa 57 (4): 546-559.

Held, D. 2010. Cosmopolitanism: Ideals and Realities. Cambridge: Polity Press.

Illich, I. 1973. Tools for Conviviality. New York: Perennial Library.

Lapina, L. 2016. "Besides Conviviality: Paradoxes in Being 'At Ease' with Diversity in a Copenhagen District." NJMR 6 (1): 33-41.

Levitas, R. 1990. The Concept of Utopia. Syracuse, NY: Syracuse University Press.

Levitas, R. 2013. Utopia as Method: The Imaginary Reconstitution of Society. Basingstoke: Palgrave Macmillan.

Lionnet, F., and S. Shih, eds. 2011. The Creolization of Theory. Durham, NC: Duke University Press.

Mignolo, W. 2012. Local Histories/Global Designs: Coloniality, Subaltern Knowledges, and Border Thinking. Princeton: Princeton University Press.

Monahan, M. J. 2011. The Creolizing Subject: Race, Reason, and the Politics of Purity, 1st ed. Ashland, OH: Fordham University Press.

Neal, S., K. Bennett, A. Cochrane, and F. Mohan. 2013. "Living Multiculture: Understanding the New Spatial and Social Relations of Ethnicity and Multiculture in England." Environment and Planning C: Government and Policy 31 (2): 308-323. https://doi.org/10.1068/c11263r. 
Nowicka, M., and S. Vertovec. 2014. "Introduction. Comparing Convivialities: Dreams and Realities of Living-with-Difference." European Journal of Cultural Studies 17 (4): 341-356.

Nowicka, M., and T. Heil. 2015. "On the Analytical and Normative Dimensions of Conviviality and Cosmopolitanism." Lecture Held on 25 June 2015 at the Eberhard Karls University Tübingen. Available from: https://www. euroethno.hu-berlin.de/de/forschung/labore/migration/nowicka-heil_onthe-analytical-and-normative-dimensions-of-conviviality.pdf. Accessed June 20, 2019.

Valluvan, S. 2016. "Conviviality and Multiculture: A Post-integration Sociology of Multi-ethnic Interaction." Young 24 (3): 204-221.

Wise, A., and G. Noble. 2016. "Convivialities: An Orientation." Journal of Intercultural Studies 37 (5): 423-431. https://doi.org/10.1080/07256868.2016. 1213786.

Open Access This chapter is licensed under the terms of the Creative Commons Attribution 4.0 International License (http://creativecommons.org/licenses/by/ $4.0 /$ ), which permits use, sharing, adaptation, distribution and reproduction in any medium or format, as long as you give appropriate credit to the original author(s) and the source, provide a link to the Creative Commons license and indicate if changes were made.

The images or other third party material in this chapter are included in the chapter's Creative Commons license, unless indicated otherwise in a credit line to the material. If material is not included in the chapter's Creative Commons license and your intended use is not permitted by statutory regulation or exceeds the permitted use, you will need to obtain permission directly from the copyright holder.

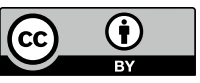

